\title{
ORAL ASSESSMENT AS A STRATEGY FOR DECOLONISING EDUCATION
}

\author{
Tracy Te Wake
}

\section{INTRODUCTION}

How do we decolonise education in order to improve outcomes for Māori that contribute to increased capacity for success and contribution in the workplace and the wider community?

This paper was born out of my experience working within the compulsory education sector seeking to decolonise/ transform the education system, and as a learner on the Bachelor of Leadership for Change programme. After facilitating a kaupapa Māori learning experience as part of my third-year project for the Bachelor's programme, an opportunity arose to advocate for a more fitting assessment - one that acknowledged mātauranga Māori and the various forms within which this knowledge can be expressed, and to make space for indigenous ways of capturing learning.

In this case, it involved advocating for a change to Otago Polytechnic's assessment policies in order to submit the required written report orally. A variation of assessment was granted, allowing an oral submission of the report along with a supplementary written piece providing a persuasive justification of why oral assessment is an appropriate assessment strategy to adopt for capstone assessments. The audience for the supplementary written piece was the collective responsible for verifying and supporting the design of programmes, courses and assessments and for making decisions around assessment policy. The following paper formed the basis of that supplementary written piece.

Set against the historical backdrop of education in Aotearoa, in this discussion I intend to consider how and by whom knowledge has and continues to be framed, valued and measured. I will discuss the use of the education system as a vehicle of oppression for Māori and the Crown's engagement in initiatives to address the disengagement and poor educational and, consequently, life outcomes for Māori. I will address the dominant discourse that considers reading, writing and mathematics as the sole determinant of success, and discuss Māori efforts to counter this narrative through the rich oral tradition of Māori, that has for generations ensured the passing of knowledge from one generation to the next.

I propose that we create space for and validate Te ao Māori perspectives on defining, framing and measuring educational success, with particular regard to oration as a valid capstone assessment. I believe that when true partnership and power-sharing is actioned, Te Tiriti o Waitangi provides us with the ideal blueprint for the way ahead that will benefit not only Māori, but all learners. Te Tiriti o Waitangi calls us to do more than just engage in dialogue, but to put action to our thinking in order to effect change.

I hope this article supports those involved in assessment processes to reflect on their professional practice, and on the different ways that learners could demonstrate the outcomes expected of graduates. 


\section{WHAKAPAPA}

In addressing why oral assessment is an appropriate assessment strategy to adopt for capstone assessment, I begin by locating myself within a journey that began with my tupuna and will continue with my mokopuna long after I have departed this world. The pepeha of my people speaks to the interconnectedness and interdependence of people and place, specifically to the Whānganui Awa.

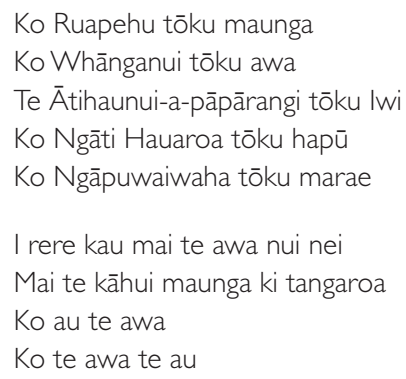

(The river flows from the mountain to the sea, I am the river, the river is me)

Within this pepeha lies the deeper understanding and knowledge of a people who respect the sacred ancestral river and ecological systems that support life and the ways in which they have influenced and continue to influence the natural order and values of the river people. The rich oral traditions of a people that holds sacred hidden taonga, awaiting their time to be revealed. This is in line with my people's understanding that the whenua holds and speaks to and of ancestral knowledge and ways of knowing and being.

Along with my own life experiences, this understanding has framed my thinking and produced my life mantra: "Nga taonga o te pouri, me nga māpihi maurea o nga wahi ngaro:" "There are treasures to be found in the dark and hidden places." Treasures of an ancient people, to be remembered and revealed in their time. I stand on the shoulders of my tupuna, looking backward in order to walk forward. It is from this vantage point that - in response to the question, Why should an oral representation of one's learning be appropriate for a capstone assessment? - I will argue, Why would it not?

My personal experience of growing up in a family of educators and observing their efforts to see better outcomes for Māori, along with my own experiences of racism as a student, has ignited within me a desire and belief that we can and must see change within the education sector. My time working in the alternative education sector with students who have been alienated from mainstream schooling, predominantly Māori boys, has been fraught with frustration. I have spent much time navigating bias in systems, policies and procedures that continue to perpetuate an uneven playing field for Māori. It is a system in which Māori are underperforming based on how achievement is currently defined, framed and measured. This system's dominant narrative, that determines literacy and numeracy as the sole indicator of achievement and success, is, according to Durie (2003), an incomplete one. "Being Māori is a Māori reality ... education should be as much about that reality as it is about literacy and numeracy" (Durie, 2003, p. 133). Along with Milne (2003), I would argue that a paradigm shift is needed in how we think about, define and measure educational achievement.

\section{COLONISATION OF EDUCATION IN AOTEAROA}

Historically, education has been one of the vehicles that have led to the oppression of, and poor life outcomes for, Māori. The introduction of the Native Schools Act (1857) saw secular schools set up in Māori villages where the curriculum was based on the English primary school system and taught in English. This led to the marginalisation 
of Te Reo Māori and tikanga, along with the misrepresentation of Māori history. This Act, along with the Tohunga Suppression Act (1907), which removed the role of the tohunga in passing down spiritual and specialist knowledge to the next generation, effectively worked to assimilate Māori tamariki and rangatahi by leaving the extended whānau out of the process of educating their own and undermining the very foundations of Māori society.

Te ao Māori ways of knowing and being were deliberately excluded from the education sector and replaced with Western understandings that served the purposes of the Crown and the settler community. This effectively destroyed the firm foundation upon which Māori had previously been able to succeed as Māori (Durie, 2003). Deliberate acts designed to alienate Māori from their language and ways of being led to disengagement in education that still exists today.

Milne (2016) believes that colonisation has had a profound effect on Māori, decimating economic, political, cultural and social structures by means of deliberate policies of assimilation and integration, using schooling as a platform to do this. Apple (2004) suggests that educational institutions function to distribute ideological values and knowledge, and that the technical knowledge taught in these institutions serves to legitimise the existing distribution of economic and cultural power, ensuring the ongoing production of "the type of knowledge that is needed to maintain the dominant economic, political, and cultural arrangements that now exist" (Apple, 2004, p. 19).

Educational initiatives by the Crown have been limited in their scope to affect long-term change, due to significant resourcing constraints and a focus on assessment in literacy and numeracy, as seen in the era of national standards for reading, writing and mathematics in primary and intermediate schools. More recent efforts to address the achievement of Māori, such as Ka Hikitia - Accelerating Success 2013-2017 (Ministry of Education, 2013) and Tātaiako: Cultural Competencies forTeachers of Māori Learners (Ministry of Education, 20 I I), have shifted the emphasis to recognise and explore how to engage with whānau, hapū and iwi, stressing the recognition of Te Tiriti o Waitangi in policy, Māori representation in governance, building teacher capabilities and curriculum development. However, on the whole the measures of success applied and the reporting of them have not changed.

Māori have not always underachieved educationally. Strong and healthy social structures and systems enabled Māori to embrace the written word enthusiastically and with great success when introduced by the missionaries. Mãori became literate in the reading and writing of te reo Māori and later in te reo Pākeha. During this period, Māori were more literate than the settler community and described as being quick and eager to learn (The Prow, 2020). Early missionary Samuel Marsden had a high opinion of Māori, describing Māori habits of industry as being very strong, and "their thirst for more knowledge great ... They appear like a superior race of men" (Orange, 20 I3, p. I4). Māori interest in and enthusiasm for embracing this new knowledge were due in part to the recognition of how these new-found skills and knowledge could be of benefit to, and serve the purposes of the collective at whānau, hapū and iwi level.

\section{MĀORI EDUCATION STRUCTURES, SYSTEMS AND SUCCESSES}

Māori educational systems are based on a rich oral practice that has a literacy of its own. Knowledge acquired for the day-to-day and long-term wellbeing of the individual, whānau, hapū and iwi is held within whakapapa (genealogy), whakataukī (proverbs), mōteatea (sung lament, poetry), pepeha (sayings), pūrākau (stories from the past), waiata (songs), haka (dance), kōwhaiwhai (paintings), tukutuku (latticework), whakairo (carvings) and moko (traditional tattoo), reflecting places of significance, the environment and its various elements, and the kōrero (stories) of the people.

Smith (1999) contends that these forms of Māori literacy hold just as much relevance and validity as the cultural norms of Pākeha literacy. As an example, Smith argues that whakairo (carving) is a written form of the Te ao Māori worldview and just as valid as Pākeha written text. This understanding of alternative forms of literacy, including the practice of oration, has been used for generations to define, hold and pass on knowledge, and should, as Hōhepa 
(200 I) contends, now both "inform" and "reform" literacy strategy and policy. Māori have been active in holding space for and walking out their own emancipation. Kaupapa Māori initiatives, such as Kōhanga Reo, Kura kaupapa Māori,TeWānanaga o Aotearoa, Te Wānanaga o Raukawa andTe Whare Wānanga o Awanuiārangi, have led the way with regard to bilingual and bicultural approaches to education and held space for and validated oral assessment.

In response, mainstream educational institutions have come some way, by allowing written assessment in Te Reo and oral presentations as part of formative assessment. However, I would argue that this is not far enough, and that oration is in and of itself sufficient for a capstone assessment. According to Yates (1996), kaupapa Māori approaches can provide useful and meaningful outcomes for Māori learners; having to justify kaupapa Māori approaches, Yates contends, is a subtle way of undermining its validity from the outset. I contend that in Aotearoa, under Te Tiriti o Waitangi, the validity of kaupapa Māori approaches should be a given.

\section{REDEFINING SUCCESS AND HOW IT IS ACHIEVED}

As part of the broader scope of improving educational achievement for Māori, we must address what success is, who determines what it is and how success is measured. Within the Western education system in Aotearoa, substantial weighting is given to reading, writing and mathematics as the measure of academic success - as observed in the Evaluation of Literacy and Mathematics Additional Learning Programmes for Students 2011 report (Ministry of Education, 2012). Tomlin-Jahnke (2007) believes that what counts as knowledge, how it is organised, resourced, taught and evaluated, is determined by the dominant culture, where indigenous education outcomes are compared with and measured against national (National Certificate of Educational Achievement) and international (Programme for International Student Achievement) norms and benchmarking, tests and surveys are embedded in Western hegemonic values and ideals. In order to make the necessary changes needed in education, it is vital, as Milne (2009) proposes, that we "ask the hard questions about the purpose of schools, whose knowledge counts, who decides on the norms we expect our youth to strive to achieve, and who decides on literacy and numeracy as the holy grail and almost sole indicator of achievement and success?" (Milne, 2009, p. 5).

In order to navigate a pathway forward, I suggest that we must have a historical understanding of how as a nation we got to this point, of the underlying ideology that drives assessment at tertiary level and how that influences the compulsory education sector, allowing the system to continue to perpetuate the status quo.

Assessment drives curriculum content and delivery, expectations and resourcing within educational institutions and the broader community in Aotearoa. The education system has failed to recognise and give equal weighting to Te ao Māori perspectives on what constitutes success and appropriate ways of measuring that success. Exploring and embracing alternative measures of achievement, in this case oration, has the potential to be of benefit not just to Māori, but to the wider student body. Offering opportunities for growing a shared understanding of different knowledge systems could also open up alternate pathways of assessment. This is in line with the thinking of Barnhardt and Kawagley (2005), who suggest that teaching indigenous knowledge systems in parallel with Western knowledge systems provides opportunities for comparison in order to identify which is more useful under certain circumstances. They argue that this approach will potentially make way for a robust education system for both native and non-native learners.

I believe that indigenous ways of holding knowledge do not require the validation of the dominant group to become valid; they already are. It is at the point where we turn backward to walk forward, according to the kōrero of my tupuna, that we allow space for remembering, in order to navigate our path into the future.

I would argue that Te Tiriti o Waitangi provides an excellent model for true partnership and power-sharing that would and should see a shift in educational outcomes for Māori. In the Te Kawai Ora report (200 I), literacy is defined as the lifelong journey of building the capacity to read and shape Māori and other worlds. The report suggests that in order to ensure better outcomes for Mãori, a shift is required in our thinking about nationhood 
building. This is encompassed by the ancient wisdom expressed in the whakataukī "Nāu te rourou, nāku te rourou, ka ora te manuhiri:"' "From your food basket and from mine, the wellbeing of the people will be assured." As well as drawing out themes of authenticity and inclusion from this whakatāuki, the reference group indicated the need for partnership to be paramount moving forward, stating thatTe Tiriti o Waitangi is fundamental to the nation-building process of Aotearoa and provides an excellent model of partnership.

True partnership would and should see equal weighting given to Te ao Māori understandings of what success is, and how success is measured. UnderTe Tiriti o Waitangi, kaupapa Māori understandings and forms of literacy, such as oration, should be a given and not relegated to Te ao Māori spaces and learning institutes. It is going to be vital that we do not merely recognise that Te ao Māori perspectives count, but that course design, content and assessment procedures reflect this. It is therefore imperative that we make space for Te ao Māori perspectives and practices of acquiring knowledge and measuring learning, including oration as an appropriate capstone form of assessment. Courage will be required to engage in the paradigm shift needed, along with a commitment to fulfil our obligations of true partnership and power-sharing.

It is evident that our colonial history has directly contributed to disengagement and poor educational outcomes for Māori. Attempts by the Crown to address Māori success in a system driven by Western hegemonic values and ideals have failed to recognise and give equal weighting to Te ao Māori perspectives about how knowledge is defined, framed and measured. The underlying ideology that informs the education system and drives assessment at tertiary level influences the compulsory education sector. As a result, I contend that change needs to be made at this capstone level, making space for oration as a valid form of capstone assessment. I believe that Te Tiriti o Waitangi is a living document that affords us as a nation a space full of potential. As two peoples, we can retain our unique cultural ways of knowing and being and recognise and value that of the other, in order that as equals we may walk into the future together to discover new horizons. This is the hope of my tupuna and the spirit of Te Tiriti o Waitangi, that continues to cry out from the whenua, calling us to walk this journey with authenticity and integrity, calling us back to its original purpose and intent. Having played a lead role in the oppression of Maori historically, education now stands at the threshold of time, with the opportunity to be a vehicle of change that contributes significantly to the emancipation of Mãori in this hour, ultimately building a better Aotearoa for all.

As I stand on the shoulders of my tupuna, looking backward in order to walk forward, it is from this vantage point that I respond to the question. Why should an oral representation of one's learning be appropriate for a capstone assessment? Again, I contend, why would it not?

\section{CONCLUSION}

Writing was never the challenge. To write would have been the easier option, requiring less time, effort and energy. The challenge was to become the change I wanted to see, to advocate and make space for Te ao Māori ways of defining, framing and assessing knowledge. The risk was potentially not being awarded a degree in taking such a stand. However, in not making a stand the risk was that we continue to do what we have always done in education, propping up a system that has historically not served the purposes of my people in particular, meaning that another generation is impacted negatively. My stance was - if not me, then who? If not now, then when? My decision to claim back indigenous spaces, and to raise their value, was based on what I believed was best for the collective and not necessarily for myself. In challenging the dominant discourse within education regarding how knowledge and learning is captured and measured, and in creating space for others, I know that I am playing my part in ensuring an improved educational landscape for my mokopuna.

I was awarded my degree and have taken this opportunity to publish this article in order to contribute to my ongoing work for wider systemic change. 


\section{GLOSSARY}

ao - to dawn, bright, world

Aotearoa - Māori name for New Zealand ("long white cloud")

$\mathrm{au} / \mathrm{ahau}-\mathrm{I} / \mathrm{me}$

awa - river

hapū - kinship group, subtribe

taonga - treasures / cultural aspirations

iwi - extended kinship group / people descended from a common ancestor

Ka Hikitia - to step up, to lift up or to lengthen one's stride

kaupapa - purpose, collective philosophy

kōhanga reo - Māori-language preschool

Māori - indigenous people of New Zealand

mārae - local meeting house

maunga - mountain

pākeha - non-Māori

pepeha - tribal saying, tribal motto, set form of words

reo - Māori language

tangaroa - ocean / sea

Tiriti o Waitangi - Treaty of Waitangi

tupuna - ancestors

wānanga - extended (sometimes overnight) educational seminars or gatherings

whānau - extended family structure

whenua - land

Contact details: tracyt@waihicol.school.nz

Allen-Tihu, J. (2015). Whakapapa Wānanga, Kauangaroa, Whānganui. New Zealand.

Apple, M.W. (2004). Ideology and curriculum (3rd ed.). New York, NY; London, UK: Routledge Falmer.

Barnhardt, R., \& Kawagley, A. O. (2005). Indigeous knowledge systems and Alaska Native ways of knowing. Anthropology \& Education

Quarterly, 36(I), 8-23. https://doi.org/10.1525/aeq.2005.36.1.008.

Bishop, R., \& Glynn,T. (1999). Culture counts: Changing power relations in education. Palmerston North, NZ: Dunmore Press.

Bishop, R., Berryman, M., Tiakiwai, S., \& Richardson, C. (2003). Te Kotahitanga: The experiences of Year 9 and 10 Māori students in mainstream classrooms. Wellington, NZ: Ministry of Education. 
Blank, A., Kingi, H., \& Houkamau, C. (2016). Unconscious bias and education. A comparative study of Māori and African American students. Retrieved from http://www.oranui.co.nz/images/oranui_reports/unconscious-bias-and-education.pdf

Durie, M. (2003). Nga kahui pou: Launching Māori futures. Wellington, NZ: Huia.

Durie, M. (1989). Tino rangatiratanga. In I. H. Kawharu (Ed.), Waitangi: Māori and pakeha perspectives of the Treaty of Waitangi. Auckland, NZ: Oxford University Press.

Education Review office. (201 I). Alternative education: Schools and providers. Retrieved from https://www.ero.govt.nz/publications/ secondary-schools-and-alternative-education-april-20 I I/

Hōhepa, M. K. (200 I). Maranga e te mahara: Memory arise - Learning, culture and language regeneration. Paper presented to the New Zealand Association for Research in Education Conference, Christchurch Polytechnic Institute of Technology.

Lourie, M. (20 I 8). Biculturalism:What could it mean in education in Aotearoa New Zealand? New Zealand Journal of Teachers'Work, 15(I), 24-27.

Māori Adult Literacy Working Party. (200 I). Te Kawai ora: Reading the world, reading the word, being the world.Wellington, NZ: Ministry of Māori Development

Milne, A. (2009). Colouring in the white spaces - Cultural identity and learning in school. Retrieved from https://staticl.squarespace. com/static/57438b77f699bbfae400bbca/t/5750ead5f850827880ea8e39//464920802604/Colouring+in+the+White+Space s_+Cultural+ldentity+and+Learning+in+School.pdf

Milne, A. (2016). Where am I in our schools' white spaces? Social justice for the learners we marginalise. Middle Grades Review, I (3), Art. 2.

Ministry of Education. (2012). Evaluation of literacy and mathematics additional learning programmes for students 201 I. Retrieved from https://www.educationcounts.govt.nz/publications/numeracy/evaluation-of-literacy-and-mathematics-additional-learningprogrammes-for-students-201।

Ministry of Education. (2013). Ka hikitia - Accelerating success 2013-20 I 7. Retrieved from https://www.education.govt.nz/our-work/ overall-strategies-and-policies/ka-hikitia-accelerating-success-201320 I7/

Ministry of Education. (2007b). The New Zealand curriculum. Wellington, NZ: Learning Media

Ministry of Education. (20I I). Tātaiako: Cultural competencies for teachers of Māori learners. Retrieved from https://educationcouncil. org.nz/required/Tataiako.pdf

Ministry of Social Development. (2008). The social report: Te pūrongo oranga tangata: Indicators of social wellbeing in New Zealand. Retrieved from http://socialreport.msd.govt.nz/documents/2008/social-report-2008.pdf

Orange, C. (1987). The treaty of Waitangi. Wellington, NZ: Allen and Unwin, Port Nicholson Press.

Shirley, I. (1979). Planning for community. Palmerston North, NZ: Dunmore Press.

Smith, L.T. (1999). Decolonizing methodologies: Research and indigenous peoples. New York, NY: Zed Books \& Dunedin, NZ: Otago University Press.

Smith, T. (1999). Doing research from home:Tangata whenua issues and Māori research. In Te Pūmanawa Hauora (Ed.), Proceedings of Te Oru Rangahau: Māori Research and Development Conference (pp. 246-248). Palmerston North, NZ: School of Māori Studies, Massey University.

State Services Commission. (2005). Timeline of the treaty. Wellington, NZ: Author.

Stewart, G. (20 18). Rebooting biculturalism in education in Aotearoa-New Zealand. New Zealand Journal of Teachers'Work, I5(I), 20-23.

The Prow. (2020). Maori and education. Retrieved from http://www.theprow.org.nz/maori/maori-and-education/\#.XzCeZhMzaqD

Tihu, T. (n.d.) Kaupapa Māori Discussion. Tawata, New Zealand.

Tihu, T. (n.d.) Whakapapa Discussion. Taumarunui, New Zealand.

Tomlins-Jahnke, H. (2007). The place of cultural standards in indigenous education. Paper presented at the American Education Research Association Annual Conference, Chicago, Illinois.

Yates, B. (1996). Striving for tino rangatiratanga. In J. Benseman, B. Findsen, \& M. Scott (Eds.), The fourth sector: Adult and community education in Aotearoa/New Zealand (pp. 95-I I I). Palmerston North., NZ: Dunmore Press. 